\title{
GANESA AND HIS CULT IN CONTEMPORARY THAILAND
}

\author{
Ruchi Agarwal* \\ Social Science Division, Mahidol University International College, \\ 999 Buddhamonthon 4 Road, Salaya, Nakorn Pathom 73170, Thailand \\ e-mail: ruchi.aga@mahidol.ac.th \\ William J. Jones ${ }^{* *}$ \\ Social Science Division, Mahidol University International College, \\ 999 Buddhamonthon 4 Road, Salaya, Nakorn Pathom 73170, Thailand \\ e-mail: william.jon@mahidol.ac.th
}

Published online: 15 July 2018

To cite this article: Agarwal, R. and Jones, W. J. 2018. Ganesa and his cult in contemporary Thailand. International Journal of Asia Pacific Studies 14 (2): 121-142, https://doi.org/10.21315/ijaps2018.14.2.6

To link to this article: https://doi.org/10.21315/ijaps2018.14.2.6

\begin{abstract}
Ganesa has long been familiar to the people of Thailand but increasingly evident are the Ganesa cults flourishing in Bangkok. In the process, the deity appears to be acquiring new roles and functions. Ganesa now serves in a number of capacities for some; he is a "fixer," a deity of last resort that can help devotees to overcome obstacles in their lives. Not surprisingly, the growing popularity of the deity is reflected in a rapidly expanding trade in Ganesa images and icons, displayed in shopping mall exhibitions in a variety of forms, colours, shapes and sizes. Readily available at most of Bangkok's major retail outlets, Ganesa icons are traded online via social media. This paper attempts to explore this phenomenon, both by examining shifting belief practices associated with Ganesa locally and by looking at how these shifts are reflected in the evolving trade in Ganesa iconography. Considering both together, the authors will demonstrate that Ganesa cult is presently the focal point for a number of people, each with its own unique approach to the deity, powers and representation.
\end{abstract}

Keywords: Cult, icons, Ganesa, religion, religion in Thailand 


\section{INTRODUCTION ${ }^{1}$}

The September 2015 Ganesa festival at the Sri Maha Mariamman Indian Temple $^{2}$ on a busy business street in downtown Bangkok drew tens of thousands of visitors. Known for heavy traffic during rush hours, the street literally closed down to traffic making way for commuters to explore the festivities by foot. Despite heavy rain, devotees, merit makers and blessing seekers flocked to the temple grounds to be part of the celebrations. Roadside altars (set up within a radius of around two kilometers around Sri Maha Mariamman Temple) and performances included transvestite dance routines, Thai country music (luk thung) ${ }^{3}$ performances and Brahmin prayers. Devotees of all social classes, genders and ages brought their personal Ganesa idols, popularly known in Thai as Pra-Phikanet ( พระพิฆีเนศ)), enshrined on beautifully decorated temporary alters and chanted verses in praise of Ganesa. Each alter is unique to itself demonstrating eye catchiness, multi-coloured and involved arrays of religious activities ranging from aarti to free horoscopic consultations for passers-by. Celebrations continued late into the night followed by cleaning of the street by devotees, including TV celebrities (seen as a service that would bring spiritual merit). Devotees pay their last respects to Ganesa, present both at the altars and in Sri Maha Mariamman Temple as they bid their farewell to the festival with a promise to join again. Also evident is the expansion of Ganesa celebrations each year with more Buddhist and diasporic Hindu temples organising festivities to celebrate Ganesa's birthday.

Some may see Ganesa as a god of the Hindus living in and outside of India representing the Hindu identity and nationalism especially with a Hindu nationalist government in power in India. Others may argue that Ganesa is one of the many Hindu gods that bind the Hindu diaspora community together. However, what is less known about this deity is his popularity among the non-Hindu community in Thailand. Ganesa at present is one of the more popular non-Buddhist deities among the predominately Buddhist population of Thailand. One can clearly see Ganesa's presence through the existence of physical iconography in Buddhist temples, private and public shrines, market areas and other public places. However, scholars in Thai studies have generally ignored Ganesa's increasing evident existence in Thai religiosity. This paper aims to fill this gap by exploring Ganesa's popularity through primary data collected through empirical observation and personal interviews with practitioners. The sample population was drawn from religious icon vendors who provided personal insights into various meanings and their own personal interpretations of their products in relation to Ganesa. 
The Thai religious market is comprised of the production, consumption and exchange of charisma (Tambiah 1984; Jackson 1999; McDaniel 2011), merits (Kitiarsa 2008), Buddhist and non-Buddhist goods (Kitiarsa 2005; Kitiarsa 2012; Jackson 1999) and religious tourism. Huntington and Shaw (1951: 18) suggest, "every religion is at least modified by its surroundings, especially those of its birthplace." They further argued that objects of worship are frequently determined by geographic as well as cultural factors. This indicates the geographic aspect of religious diffusion as well as the localised modification that religions can undergo given the agency of individuals (Park 2004). In the Thai context, there is a physical geographic linkage of religion and marketplace (including Buddhist and non-Buddhist) and the economy (Wilson 2008). The localised linkage can be seen through localised beliefs, hybridised adoption and practices of devotees. Religious consumers are involved in dual relationship; first relationship of a spiritual nature and second an economic relationship. Furthermore, the relationships are multilayered, in that, they encompass both a personalised character as well as a localised hybridised version of mainstream religions found in Thai society. The resulting effect is the growing competition among the providers of religious goods and services, which create what Taylor (2008) calls a "religious marketplace" (cited in Scott 2017). An interesting example is of a long-deserted shrine built in the 1990s on a large commercial Bangkok city thoroughfare of Pinklao Road. ${ }^{4}$ The shrine was commissioned in 1990 by the real estate developer Phongsirichai Complex as a personal shrine of protection. Her Royal Highness Princess Bejeratana Rajasuda then inaugurated the shrine in 1992 in a grand ceremony. Initially dedicated to and having a statue of Siva, ${ }^{5}$ the shrine was refurbished beginning in 2007 and finished in 2009 being rebranded and having a new statue in line with the increasing popularity of Heramba Ganesa. ${ }^{6}$ This is one of the many shrines opened in Bangkok and suburban areas featuring regular ceremonies officiated by Brahmins and spirit mediums. The Ganesa festival around Sri Maha Mariamman and the Pinklao shrine are just one of the many examples of Ganesa's popularity. Ganesa's popularity has given rise to cult like practices reflected in expanding trade in icons where the deity is depicted in different forms, colours, shapes and sizes. 

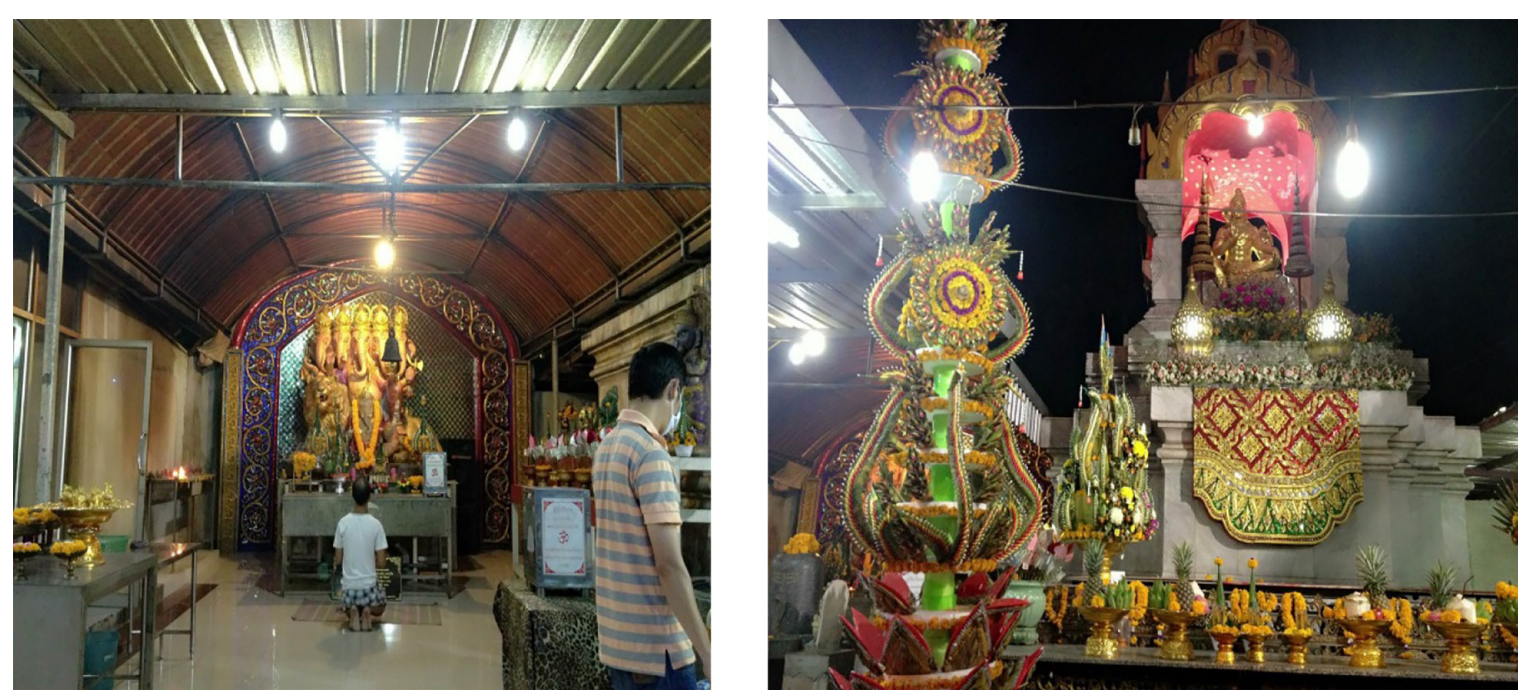

Figure 1: The image on the left is the Siva shrine after renovation into Heramba Ganesa. The image on the right is the original Siva shrine commissioned in 1990.

\section{WHO IS GANESA OR PRA PHIKANET?}

Ganesa, ${ }^{7}$ one of the principle Hindu deities is easily recognisable with its elephant head and a broken tusk. The mythology surrounding Ganesa has flourished since the seventh century A.D. through the Puranic texts, with numerous stories making Ganesa a popular deity throughout India (Sukumar 2003: 75). According to Dhavalikar, Ganesa underwent a transformation from being considered as a minor god in the Hindu pantheon to being in the hierarchy of major divinities in the late Gupta period of the sixth century A.D. Ganesa gained importance in a relatively short period with the Ganesa cult coming into being in the ninth century A.D. The primary reason for the emergence of Ganesa's importance is the transformation from a malevolent Vinayaka (creator of obstacles) into the benevolent Ganesa (remover of obstacles) (Dhavalikar 1991: 49). The transformation from a minor to major deity and role from negative to positive association followed a hierarchical path where elite were the first to engage and later spread to commoners (Sukumar 2003: 74 cites Ghurye 1962: 51-62). Dhavalikar argues that Ganesa's popularity reached its peak in the early medieval period sometime in the eighth century A.D. with even Buddhist and Jains beginning to worship Ganesa. Ganesa worship spread beyond India to other parts of Asia with Dhavalikar even labelling Ganesa as the god of Asia (Dhavalikar 1991: 49). Later in the eighteenth century, the Maratha Empire introduced Ganesa Chaturthi ${ }^{8}$ to the Maharasthrian region. ${ }^{9}$ The 1890's public celebration of Ganesa Chaturthi in Maharashtra introduced by Lokmanya Tilak ${ }^{10}$ was a way of uniting people earlier separated by the 
caste system. ${ }^{11}$ Tilak recognised the wide appeal Ganesa had as a god for everyone and thus promoted Ganesa Chaturthi as a national festival to build unity and additionally to assert a Hindu nationalist identity during the period of British colonial rule. Large public images of Ganesa in pandals and Tilak later introduced the practice of submerging the images in the water on the tenth day of the festival (Lochtefeld 2002: 698). This served as a meeting point for people of different castes and communities during the period when the British colonial government restricted all forms of political opposition. In Bengal, revitalising the worship of Durga and Kali also emerged as a form of cultural and political resistance against British colonialism. By the early twentieth century, Durga puja turned into public celebrations breaking down barriers such as religion, caste, gender among others codified into buildings and spaces through restrictions based primarily on caste and religion (Purkayastha 2016: 96-98). ${ }^{12}$ The emergence of public celebrations of Ganesa or Durga or others during the colonial period are beyond the scope of this research. However, a brief reference especially to the cult of Ganesa in India highlights two things. Firstly, the historical presence of the cult in its birth place, and secondly, the quality of Ganesa as a remover of obstacles. ${ }^{13}$ This is evident with the fact that public celebrations of the Ganesa festival helped in unifying people earlier separated into separate communities based on caste and religion. Historically, the importance of Ganesa as a deified cult figure was based on progress and transformation from a negatively associated deity into a positively associated deity. This is important concerning the local context in that history provided a deity figure with an already preexisting cult, this then could be transmitted, mimicked and shaped according to local socio-cultural contexts.

\section{THAI PROSPERITY CULTS}

Anthropologist Joy Hendry (1999: 12) suggests that as societies increase in complexity due to economic dislocation, technological advancement as well as increased competitiveness along multidimensional field's people live with contending and often conflicting perspectives towards themselves and others. Religion can often act as a shock absorber for individuals who are trying to sort their lives in a stable manner in regards to external stress and pressures. Religious movements and religious ideas have encouraged people to engage with different cults, sects and various belief systems that can fulfil individual wishes. Religious cults can also provide multilayered functions with individuals. In contemporary Thailand, this is demonstrated with the phenomenon of a person who is suffering from a sickness or ailment who may consult a spirit 
medium as well as a physician and visit a temple to pray for recovery while giving alms to increase their karma. Along with Theravada Buddhism, there is a strong presence of animism, folk Brahmanism and Chinese traditions, among others. A number of scholars have conducted research on different cults in Thailand ranging from cults of magical monks, significant historical figures (Stengs 2012), bodhisattvas or ghosts (Jackson 1999, Kitiarsa 2012, 2010, 2008, and 2005). Previous research has shown that Thais engaged in cults to maintain their associations with Theravada Buddhism while having no intention to revolt against conventional Buddhist or state authorities. Devotees also generally combine principles from Buddhism into their cultic practices (Kitiarsa 2008: 128). Jackson (1999) further suggested that different religious phenomena (like magic, practices related to living and dead Buddhist saints, senior monks, royal spirits, etc.) should be grouped together and described as prosperity religions or cults. This is because their beliefs and practices focus more on wealth and luck than salvation (Jackson 1999: 49).

Kitiarsa (2012) as well emphasises on a shift towards seeking material wealth and protection where traditionally amulets and other religious items served the purpose of protection and moral strength. However, in times that are more recent there has been a shift towards seeking religious help in increasing and protecting the material wealth (Kitiarsa 2012: 97-98). There appears to be a growing need among urban elites for psychological, moral and spiritual protection to enhance their existing wealth and power (Kitiarsa 2012: 42). Such yearning for spiritual protection has given rise to a number of cults in Thailand; some maintain their popularity while others faded over time. One of the most common features among these cults is there emergence during the period coinciding with Thailand's economic boom (1980s and mid-1990s). During this period, there was an increased search for spiritual protection during times of stress and anxiety (a byproduct of consumerism). According to Jackson (1999), rapid economic growth and changes in Thailand's politics and modern life intensified the spread of prosperity cults such as Luang Phor Khoon (supernatural monk) cult and the Guan Yin cult (Jackson 1999: 269, 299-300). Additionally, the rapid decline of state involvement in religious issues added to the emergence of cults on par with organised Buddhism (Jackson 1999: 286-288).

Kitiarsa (2010) has placed emphasis on the highly hybridised nature of Thai religions. Thai Theravada Buddhism has inculcated many alternative beliefs from different sources such as different Hindu gods, local spirits, ghosts, dead baby spirits and amulets among others. The hybridised Thai religiosity has extended beyond temples to mass media and the marketplace-giving rise 
to what Jackson (1999) sees as prosperity religion. Kitiarsa perceives spiritmedium cults, ${ }^{14}$ flourishing all over Thailand, as providing strong foundations to not only syncretic but also the hybridised Thai religiosity (Kitiarsa 2005: 484486). Stengs (2012) argues that emergence of the cult of King Chulalongkorn (Rama V) as a symbol of "Thainess" emerging when tensions between local certainties and the effects of global processes became more pronounced and visible. ${ }^{15}$ She defines "Thainess" as being able to "integrate modernisation in a Thai manner" in addition to being a symbol of "pride for not being colonised." Stengs suggests that the cult emerged in 1987 when Thailand started to experience rapid economic growth leading to the emergence of a new and large urban middle class. This new urban middle class faced uncertainties and anxiety in maintaining their economic position, which led to a search for spiritual protection to maintain their prosperity thereby encouraging further interest in various cults (Stengs 2012: 138-140).

For a Thai worshipper, being involved in different religions or cults creates no conflicts with their Buddhist association. As McDaniel (2011) explains, Thai Buddhists are active negotiators and patrons of ideology and innovation who negotiate with the modern age rather than blindly accepting it. He sees Buddhist practitioners as being socially engaged in addition to their ascetic life and responding to changes according to time. McDaniel sees Thai Buddhists as "neither static practitioners nor conservative reactionaries" (McDaniel 2011: 7-9). In Lovelorn Ghost and the Magical Monk: Practicing Buddhism in Modern Thailand, McDaniel explores the cult of Mae Nak (lovelorn ghost) and Somdet To (magical monk). McDaniel rightly shows that the believers of the two cults are more like dedicated fans, rather than dedicated devotees. Thai people could be a fan of one spiritual figure and switch to another according to personal need, but may not lose their admiration to the original figure. McDaniel argues that for most Thai people it is not important whether the religious figures or amulets are associated with Hinduism or Buddhism (McDaniel 2011: 10-11). Previous research into Thai religiosity largely falls under the umbrella function of a search for spiritual guidance and protection during periods of external stress. The Thai attitude of being a dedicated fan has only added to the emergence of different cults. The Ganesa cult in contemporary Thailand started to become visible during the boom period with the story of Ganesa performing a miracle (discussed later). However, Ganesa's popularity gained more momentum with the Thai economic crisis of 1997. The increased stress and anxiety among the population who faced increasing economic insecurity during the late 1990s prompted personal searching for religious assistance. Ganesa, whose deity identity as being a 
remover of obstacles became a fulcrum of hope and idol of security to those seeking security in unstable times.

The authors' point of departure is from the idea of "prosperity religions" as applied by Jackson (1999) and Kitiarsa (2010). Through the collection of empirical evidence through interviews and observations, the authors argue that Ganesa can be seen through the lens of a prosperity cult. This is due to devotees of Ganesa being seekers of success and wealth. The author recognises the fact that material culture plays an important role in understanding cults and the work of Kopytoff (1986) on the cultural biography of things or Miller's (1987) Material Culture and Mass Consumption are useful for further research. However, in this paper, the authors will present Ganesa's cult as among one of the many preexisting cults (Chulalongkorn cult, Jatukham cult, Kuan Yin cult, Luang Pho Koon cult, among others) or even new prosperity cults such as the Luk Thep cult in Thailand. What makes the Ganesa cult different is the historical presence of Ganesa giving Thai devotees a feeling of familiarity while not adopting anything new or foreign which may inhibit its cultural uptake. Chinese gods and Bodhisattavas are commonly worshiped locally, but due to the longer historical presence of Hinduism in Thailand, Ganesa's cult has found an easier fit into Thai religiosity. Ganesa's immense popularity over time has contributed to market competition evidenced through the icon trade.

Prosperity practices have become more prominent in recentyears because religious actions are required in response to different events (Comaroff and Comaroff 2000: 316). In the case of Thailand, wealth generated via capitalism gave rise to the prosperity practices during the period of boom and bust. The increasing needs of a structural positioning of believers and the aspiration for economic improvement lead to the search for wealth. Such aspirations brought anxiety and stress and therefore a search for spiritual guidance and protection. Ganesa, a god of removing obstacles, gained increasing popularity during the economic crisis, as people sought a god that could remove the obstacles arising while also fulfilling their aspirations. Ganesa's quality as remover of obstacles has given rise to a spiritual market of Ganesa icons with innovative compensators attached to serve the needs of religious consumers.

\section{GANESA AND THE ROOTS OF RECENT POPULARITY}

A number of previous studies emphasised the spread of Hinduism through civilisations along the Gulf of Siam, Cambodia, Vietnam and parts of Indonesia (see Coedes 1968, Mabbett 1977, Brown 1991 and Suarez 1999). However, 
there is a lack of research on the contemporary presence of Hinduism in the lived experiences of Thai people. The authors will fill this gap by focusing on the more recent (since the 1990s) and remarkable increase in Ganesa's popularity in Thailand. The authors recognise that there are a multitude of valuable and as of yet understudied temples and places of worship in Thailand that are directly Ganesa related such as the large temple at Wat Saman in Chachoengsao province. This large temple has a huge Ganesa statue and is located in remote rice fields where tourists are bused in to pray and make merit. While of interest to the authors this and other phenomena are outside the scope of this essay. Given the length and scope of this research, the authors will be confined to the anthropological and sociological aspects of the Ganesa cult as represented in spiritual multiplicity and the economic commodification of Ganesa as a deity and hybridised cult figure.

The contemporary existence of Ganesa as part of the Thai religious pantheon has its roots in 1990's India. In September 1995, a New Delhi man dreamt of Ganesa craving for milk. He rushed to the nearest temple before dawn and asked the priest for the permission to offer a spoon of milk to the small stone statue of Ganesa. Both individuals were amazed to see the milk disappear and within hours, the news spread that Ganesa magically consumed the milk (Mcgirk 1995). Millions of people flocked to different temples to offer milk to the deity, within hours more than a million litters of milk were sold, and the dairies ran dry. By the afternoon, the news spread to different parts of the world and Hindu temples in every corner of the world replicated the miracle. ${ }^{16}$ The miracle story was widely covered by both national and international media. According to a diasporic Brahmin in Bangkok, this incident was one of the reasons, which set the stage for the increasing popularity of Ganesa in Thailand. ${ }^{17}$ The milk-drinking story of Ganesa soon became viral not just among the diasporic Hindus community but also among the Thai population. This was evidenced with the long queues of diasporic Hindus and Thai devotees waiting for their turn to feed milk to Ganesa at the Hindu Samaj temple. While this event seems innocuous, the level of media attention it received led markedly to increasing the wider public's attention towards the "magical" powers, which Ganesa possesses.

Since that period, Ganesa has become commonly known and increasingly popular in Thailand through the mass production of Ganesa images and iconography embodied in statues, both large and small. Ganesa serves as both an active subject and passive object. Ganesa as a religious deity is an active subject able to embody different forms and engage in various positive deeds as needed by the consumer. Ganesa is simultaneously a passive object in the 
marketplace where the deity is commodified in numerous manners. Ganesa serves an economic objective and is a source of inspiration while providing both spiritual and materialistic guidance. McDaniel (2011) found that funding for the 2008 International Thai Studies Conference was largely funded by the sale of Ganesa images made by a sculptor from Po Chang Institute with ritual blessings performed by Phra Raja Khru Wamathepmuni who is head of the Brahmin sect of Thailand (McDaniel 2011: 207). Ganesa's popularity ever since has continued spreading to all classes of Thais including commoners and those believing in shamanism and animism. Among 200,000 of those who claim to be spirit mediums of Hindu gods, Ganesa ranked as the third, with Uma and Siva being the first two.

According to Mrs. B, ${ }^{18}$ a fortune-teller in her $40 \mathrm{~s}$, there are eras (yugs ยุค) associated with different spiritual figures. She defined the current era as the era of Ganesa (following from the previous era of Jatukham). Mrs. B herself was neither certain how a particular era began nor the circumstances of that era being associated with a particular deity. However, she did mention that one of the determinants is possibly the reading of astrological charts and the rest depends on chance of which spiritual figures get popular at which particular time. The degree of popularity is also dependent on celebrity endorsements. Popularity of cults like Somdet To and Mae Nak, Ganesa, Trimurti, Jatukham Ramathep among others have partially been the work of successful celebrities who were protected, succeeded or fallen in love due to the celebrities' association with religious figures, ritual performance, possessing amulets and offering prayers among other factors. Somdet To, born in 1788, was known through different stories of being the son of King Rama I, a great Pali scholar, abbot of Wat Rakhang, and a teacher of kings. Somdet To was known for his amulet-making skills and amulets made by him today are considered highly valuable with prices reaching up to US $\$ 200,000 .{ }^{19}$ The Mae Nak cult is widely known to Thai people with the story of Mae Nak situated in the Phra Khanong area of Bangkok and going back to the time of King Rama IV (1851-1868). Mak the husband, while serving in the army, went to war and was severely injured during battle. Nak died along with her baby during childbirth. Mak returned not knowing the events that had transpired and lived with Nak's ghosts. Later discovering Nak being a ghost, Mak hid in a local temple, Wat Mahabut, to escape Nak's ghost. Built in 1762, Wat Mahabut is now popular for its shrine of Nak with her cradling her baby. Pregnant women and those asking for babies make wishes and offer gifts including baby toys. Thai celebrity endorsements of Somdet To and Mae Nak cults are common to find in Thai society. 
McDaniel (2011) interprets the popularity of Ganesa as a product of great success stories and wealth of the worshippers of Ganesa. Furthermore, the endorsements by celebrities like Aphaphon Nakhonsawan (famous singer and actor), Anucha Tosawat and Pokon Phonphisut (action movie actors) have further added to the Ganesa popularity. Celebrity endorsements of Ganesa are common in Thailand, as the elephant god has historically been seen as a patron of the arts. Another feature adding to Ganesa's popularity is the involvement of Buddhist monks. Buddhist monks at monasteries throughout Thailand ritually do the casting of Ganesa images and amulets. On 13 December 2007, one of the largest casting and sanctification rituals of Ganesa was held at Wat Pak Nam by Luang Pho Ke, a popular Buddhist monk (McDaniel 2011: 157-158).

\section{GANESA, HIS ICONS AND THE ROLE OF SELLERS}

By drawing on Bainbridge and Stark's idea of "cults and compensators" along with the use case studies, the authors will now assess a number of Ganesa icons and the compensators attached which add to the sacred value of this religious commodity. Bainbridge and Stark (2003) see successful religious innovation or cult formation as a social process where the innovator both invents and transmits new religious ideas to others in exchange for rewards. Gaining rewards is an exchange process that evolves whereby humans create and exchange compensators involving sets of beliefs and remedies for action that substitute for immediate attainments of anticipated rewards. Compensators can be either specific or general; while magical healing of mental stress is a specific compensator, a promise to reach heaven is a general compensator. (Bainbridge and Stark 2003: 59-63). Bainbridge and Stark had earlier (1985) defined cults as social enterprises mainly involved in the production and exchange of unique and exotic compensators that people are unaware of since they migrate from an alien society (1985: 172-173). Cults may engage in a business-like model developing new compensator-systems, using attractive packaging and branding. In cults the social dynamics of socialisation and reward factors provide market opportunities and profit potentials both in the larger social setting of the cult as well as individuals who are attracted to the religious market.

Religious icons are symbols that are also part of the language of religion. They express deep layers of meaning and visualise elusive levels of human experience that words may not express. Icons are important; they are the signifiers that point to the signified (the sacred) requiring a person who knows 
and can provide specific meaning (Peirce 1998 cited in Aden 2013: 137). The interpreters in the case of Ganesa in Thailand are the icon sellers who offer compensators as signifiers and thus associating meaning to their different icons. A number of icon sellers exist in the Thai market catering to the needs of the Ganesa followers. ${ }^{20}$ According to Ms. $\mathrm{N},{ }^{21}$ nine out of ten temples in Thailand enshrine a Ganesa statue which leads to large mass market supply to the icon sellers who can cater to the needs of a variety of religious consumers ranging from Thai temples to the general population. The icon market has attracted an increasing number of sellers thus making it highly competitive. Each icon seller differentiates his or her product and offers something new to attract religious consumers. There exist three different kinds of Ganesa icons: those imported from India, those imported then modified locally with added features by the artisan, and lastly those entirely produced locally, each holding their own significance.

The 2015 Ganesa festival described earlier had different roadside alters offering gifts of incense sticks with the nametags. Some provided advice on how to worship Ganesa, while some others gave away business cards to potential religious consumers. The festival served several purposes such as being part of a religious celebration, gaining merit, seeking blessing from deities, consulting astrologers, and a venue for icon sellers to market their product ranging from religious icons to other objects of offerings. The festival provides an unregulated space for religious entrepreneurs to act as creative spiritual and cultural agents for religious seekers. Several icon sellers run their shops in traditional sites such as shopping malls and market places. While others run their business only through non-traditional sites such as Facebook social media. Mr. $\mathrm{T}$ is a vendor who set up his shop in a shopping mall in down town Bangkok in late 2015. His shop sells Chinese herbal medicine and a variety of religious icons including Chinese mythological characters like Guan Yin ${ }^{22}$ and Sun-Wukong, ${ }^{23}$ among others. However, Ganesa is a primary deity where Ganesa icons range from small to large (approximately 10 to $25 \mathrm{~cm})$.

\section{VARIETIES OF GANESAS}

\section{Locally Crafted Ganesa}

Mr. T's shop places more emphasis on the locally crafted icons as the owner prefers to promote the Thai artisanship and add features according to the customer's needs. A customised version of Ganesa is also available on demand 
but at additional cost. As Ms. L, the shopkeeper working for Mr. T, in an interview stated: ${ }^{24}$

We prefer to see images made by a Thai sculptor ${ }^{25}$ because we want to promote Thai craft skills. Like this one (as in the following picture) is imported from India, they will use the colour red and yellow. However, it differs from Thai style. Our style emphasises on arts. Under the throne and the base, we fill in the coins which have gone through the ritual blessings as well. All statues have gone through the rituals. We invited Brahmins from the Wat Khaek Sao Ching Cha (Hindu Samaj) for the ritual and the Brahmin originally comes from Kusinara city. He has lived in Thailand for 15 years now.

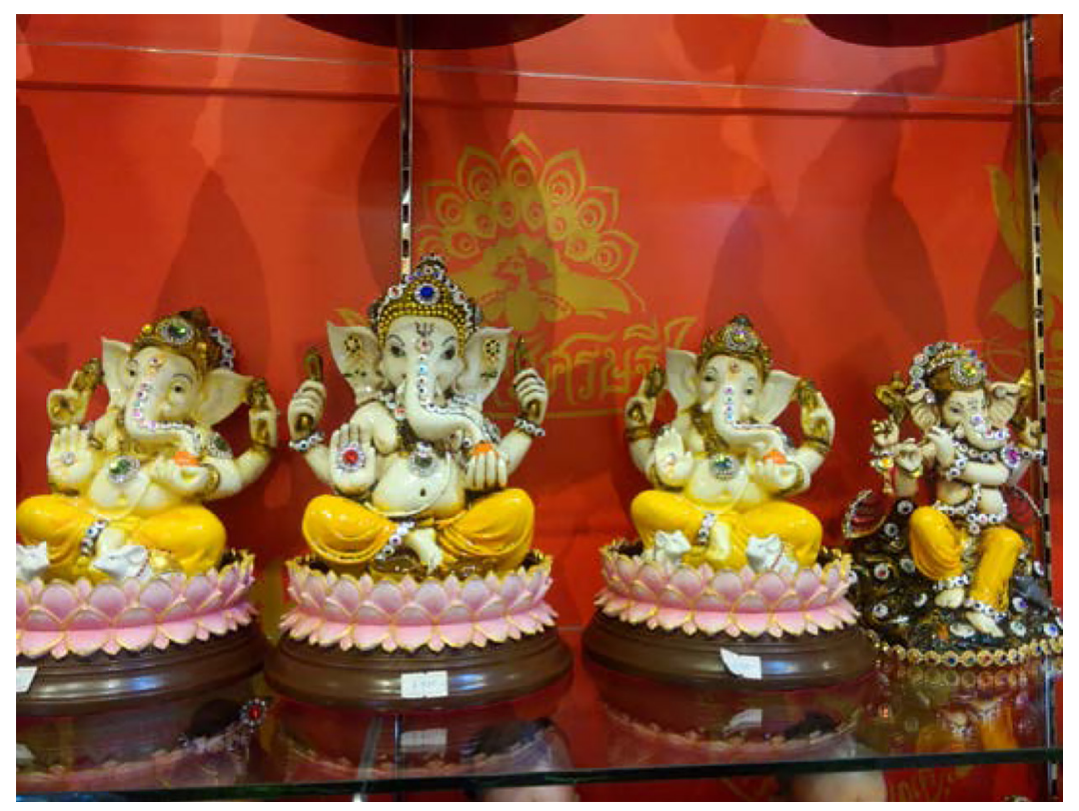

Figure 2: The three Ganesa on the lotus flower are imported from India and the Ganesa icon on the far right with coins under his throne is locally manufactured (January 2016).

Park (2004) argues that sacred sites act as focal areas, which define a sacred space and hold immense religious value. The definition of sacred sites is illusive but hold two identifying characteristics: "they are not transferable (they are valued because of their associated holiness), and they do not need to be re-established with each new generation (there is an inherited appreciation of the holiness of the site)" (Park 2004: 451). In the case of Thailand, this religious geography provides an additional value-added characteristic of Kushinagar (known in Thai as Kushinara). Kushinagar is in India and is one of the four central Buddhist pilgrimage sites. Kushinagar's significance is that of being the place where the Buddha died. Since the religious consumers are self-defined 
Buddhists, having a Brahmin from Kushinagar conduct the blessing ceremony adds significance and value to the ritual. The association of the sacred site to Hindu Brahmin's from the area attached to the Buddha has both spiritual and economic significance in that the sacred site association by transmission lends additional sacredness to the objects blessed by the Brahmin's. Ms. L emphasised that regular Ganesa worship is conducted according to the Hindu traditions with a Hindu Brahmin initiating the ceremony and is open for everyone to join. The ceremony conducted by Brahmin creates "a sacred space in which the ordinary things and activities are transformed into something sacred" (Smith 1978). Devotees that buy the Ganesa icon from the shop can easily join the ceremony and ritually invoke the sacred power in the icon; the sacralisation adds to the "repositories of power" present in religious objects (Tambiah 1984: 335). Others are also welcomed to bring their personal Ganesa icon from home and invoke sacredness through blessings from the Brahmin.

Ms. L further explains:

We also emphasise on the accuracy of Ganesa, like he needs to have a big belly, ears must be wide, big trunk. Moreover, we have the third eyes that in fact, he (Pra Phikanet) actually has it but he does not open it. And this eye stands for Siva god. By having the third eye, he will see your wish as well. In addition, for those who possess a spirit, Pra Phikanet will open your third eye and gives you more power. We also brought the Thai monk to perform the rituals because Thai people worship both religions and we want to serve both preferences. We hire dancers, invite Brahmins and Buddhist monks, we promote through social media and advertisements, and we use the best sculptor. Because we have pure faith in Pra Phikanet and we worship him then we have to make him perfect.

Here, the unique compensator is the deity watches and grants the wishes of the worshipper and when the worshipper is a spirit medium then the third eye of Ganesa blesses the spirit mediums with additional religious powers. The third eye phenomenon is a relevant signifier to the spirit mediums as the third eye of Ganesa empowers the spirit mediums to possess more spirits and further enrich their abilities to heal their followers. This multilayered compensator is at the first level operating on a level of the deity working directly to the worshippers themselves. The second level is when a religiously empowered figure is engaged in deity worship then a third level is activated providing the religious figure enhanced powers which will then operate on simple worshippers. 


\section{Wanlayaphak Ganesa}

A second form of Ganesa available at the shop is Ganesa with his two consorts and two sons named Wanlayaphak (see Figure 3). ${ }^{26}$ This form of Ganesa is unique according to Ms. L because even though the form shares some artistic similarities with the Huay Kwang intersection Ganesa shrine, ${ }^{27}$ Ms. L's Wanlayaphak Ganesa with his two wives, Buddhi $i^{28}$ and Siddhi, has an added feature of the two sons of Ganesa, Subh (auspicious) and Labh (gains). Worshipping this form brings good luck since Subh and Labh bring good luck and wealth to the devotees. This form is the Lakshmi Ganapati (Ganesa of Wealth), seated on the throne brings fame, power and charisma.

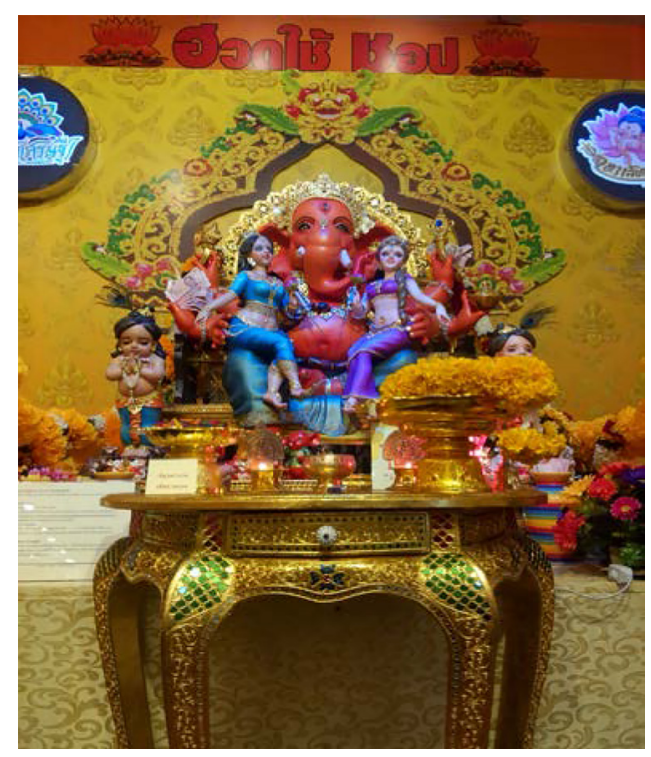

Figure 3: Wanlayaphak Ganesa.
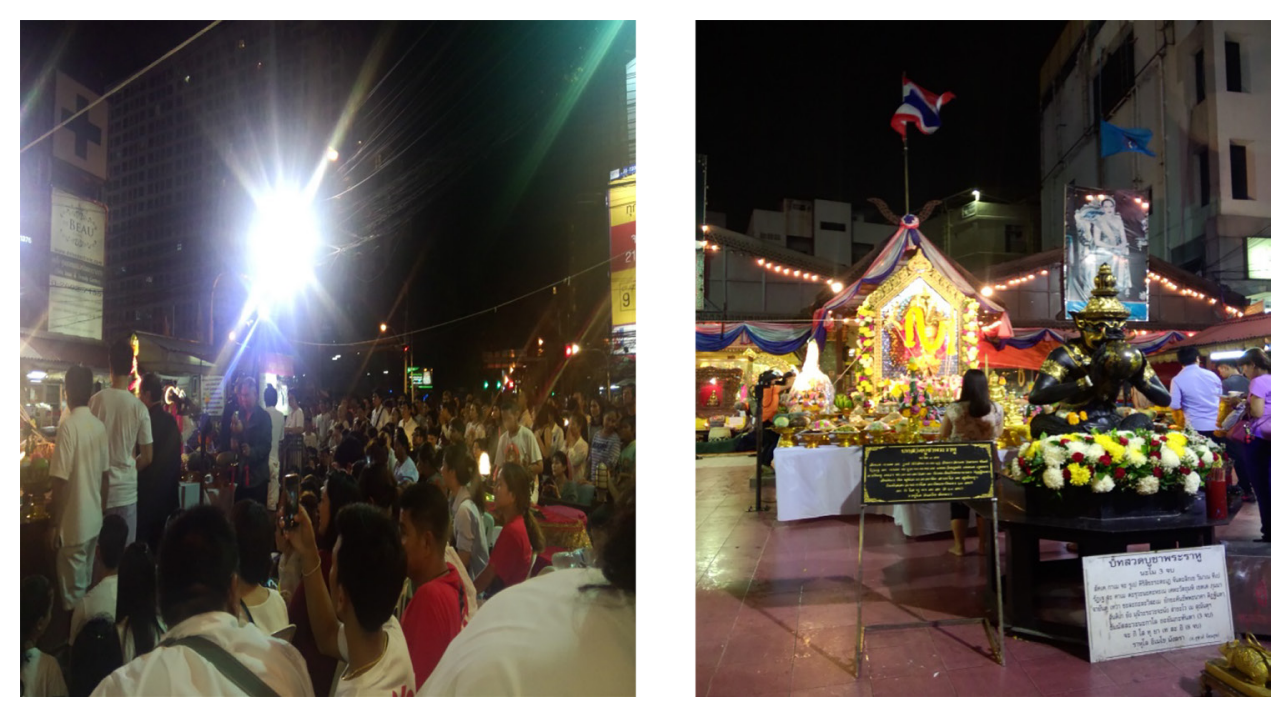

Figure 4: Famous Ganesa shrine and devotees in Huey Kwang District, Bangkok. 


\section{Baby Ganesa}

A third form of Ganesa offered is the baby Ganesa that according to Ms. L brings calmness (Sabai Jai) to the worshipper and is cute. The baby represents the symbol of power because of the young age. Ms. L recommends devotees buy and worship the Wanlayapak form of adolescence for abundance and the baby form for gaining power. The crystal ball held in Ganesa's left hand represents the unlimited wishes that the deity grants. This demonstrates product localisation as the Ganesa icons in India depict Ganesa holding a laddu (sweets), usually yellowish in colour as explained by Ms. L. The reason being laddus are Ganesa's favourite sweets and devotees are recommended to offer laddus to please Ganesa. Ms. L's shop has added uniqueness to their Ganesa by replacing the laddu with a crystal ball. The price of the baby form is 15,900 baht ${ }^{29}$ but the shop may raise the price soon as they gained a contract from a tour operator that will bring tourists directly to the shop in large numbers.

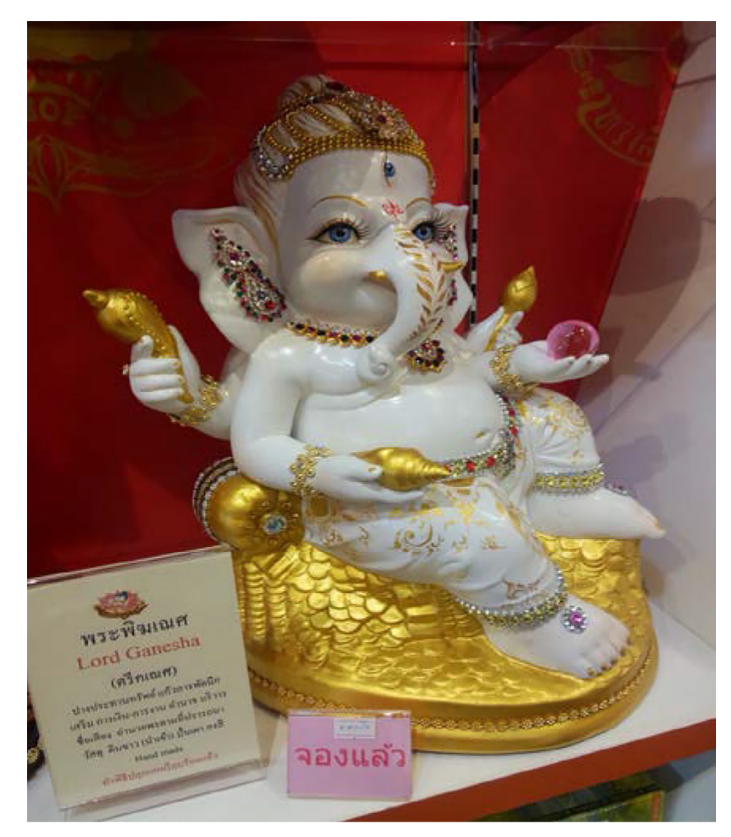

Figure 5: Baby Ganesa.

Ms. L's shop prefers to use different colours for their icon with the white coloured statues being a limited edition. They also produce the icons in other colours according to the day of birth and each colour has a spiritual meaning. For example, white represents purity and pink is for good luck. This is a major selling point for the vendor as Thai people associate colour to days of the week thus personalising significantly the religious experience with a physical icon and having that being directly associated to phenomenon in the astrological chart. According to Denis Segaller (2005), ancient Thai tradition associate 
different colours with each day of the week and each colour associates with a planet god as follows:

Table 1: Colours of the week and their planetary gods.

\begin{tabular}{lll}
\hline Day of the week & Colour & Planetary god \\
\hline Sunday & Red & Sun \\
Monday & Cream or yellow & Moon \\
Tuesday & Pink & Mars \\
Wednesday & Green & Mercury \\
Thursday & Orange or brown & Jupiter \\
Friday & Blue & Venus \\
Saturday & Black or purple & Saturn \\
\hline
\end{tabular}

Another seller, Mr. A, ${ }^{30}$ has sold Ganesa icons through social media sites like Facebook for the past three years. He initially started his Facebook page to help raise funds for alumni in Poh Chang who did not have money to pay tuition fees. Over time, there was an increase in demand for Mr. A's Ganesa icon and so he hired some people to help him mold more Ganesa icons. Mr. A as well mentions that colours are important, as he knows the preferences of his target group. He mentions that women prefer lighter colours so Mr. A would paint the icons in light shades giving a sweeter look to the deity. In addition, his Ganesa is in the sitting form, which according to Mr. A. signifies success and abundance. The compensator offered here is success and abundance if devotees worship Mr. A’s Ganesa (Figure 6).

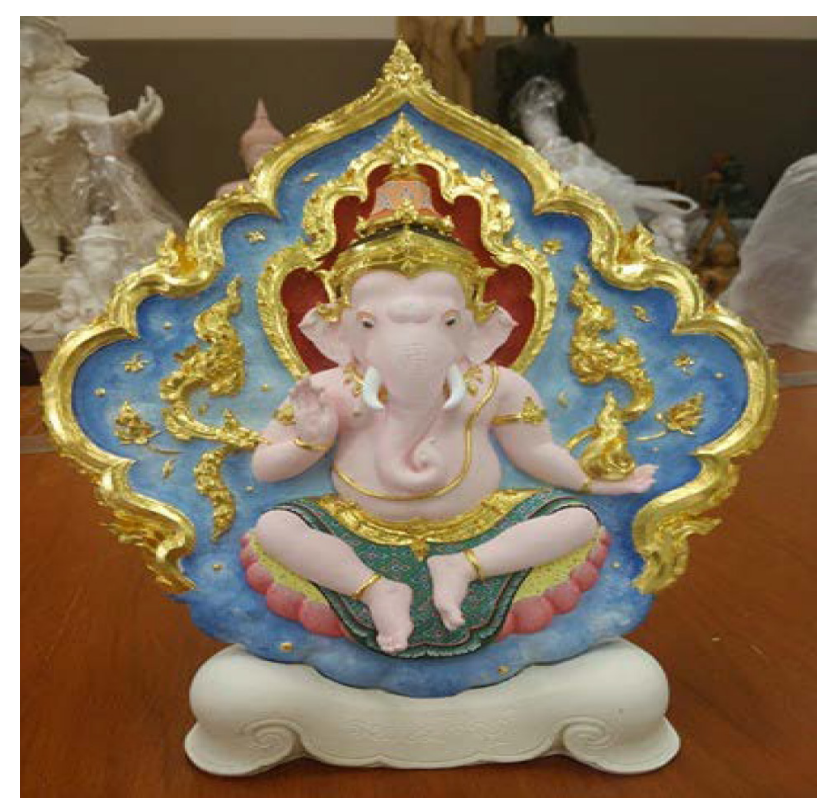

Figure 6: Sitting form of Ganesa designed by Mr. A. 
The various localised innovations and modifications of the Ganesa deity by Mr. A and Mr. A demonstrate the complexity of the Ganesa cult. They are indicative of both spiritual and economic entrepreneurship in line with local particularities in the belief that worshipping Ganesa will bring the worshipper a greater chance of success and abundance in their spiritual and material lives.

\section{CONCLUSION}

Thailand shares historic cultural and trade links with India, which have led to an abundance of Hindu influences in many aspects of Thai culture. People of Southeast Asia are well aware of Ganesa through a long history of what Coedes (1968) called Indianisation with Hinduism spreading through civilisations leaving influences still evident in language and other aspects of cultures. Although Ganesa is a residue of the historical cultural legacy, this paper focuses on the contemporary phenomena associated with Ganesa's immense popularity providing followers unique compensators that help to cope with psychological and socio-economic anxieties. The Ganesa cult, like many other prosperity cults, emerged during the period of economic boom but became more visible during the time of economic downturn. Borrowing ideas from earlier scholars, the authors see Ganesa through the lens of a prosperity cult that has attracted a big fan following since the time of the Asian financial crisis. The results from the observations and interviews during festivals like Ganesa Chaturthi and in market places reveal that Ganesa has indeed gained a large fan following over the years making Ganesa an object of veneration but at the same time an object of commodification. Mass media has also played an important role in the immense popularity of this elephant god by making information widely available and through celebrity endorsements. Ganesa's followers come from every part of society ranging from politicians to artisans to celebrities and commoners. The followers of the cult are dedicated fans who participate in festivities and possess Ganesa icons in personal spaces. With increasing interest in Ganesa, the icon market has emerged and has become increasingly competitive with icon sellers attaching meanings to the deity by offering unique compensators to the reward seekers ranging from prosperity, power, abundance and granting wishes. The varieties of compensators and meanings attached to the different icon styles have given rise to market competition based on product differentiation. Each vendor offers something different as a business strategy attracting the reward seekers. Customised services are also available with designs and colours added according to 
the need of the religious consumers. Ganesa icons in more recent times are conveniently available in department stores, weekly and weekend markets, and through social media sites.

\section{NOTES}

* Ruchi Agarwal is a senior lecturer in the Social Science Division at Mahidol University International College, Thailand. Her research interests include religions in Thailand, Hinduism in Southeast Asia, religious commodification and economies of Southeast Asia.

** William J. Jones is Program Director and senior lecturer in the Social Science Division at Mahidol University International College, Thailand. His research interests include contemporary Thai politics, ASEAN integration, EU integration and human rights in Southeast Asia.

1 The material for this paper is part of the data collected during the fieldwork for the $\mathrm{PhD}$ research on the Ganesh Cult in Contemporary Thailand during 2015 and February 2017. The Seeds Grant of Mahidol University International College funded the research. The first author would like to thank research assistant Ms. Napatrostorn Tanathanyatoranun for her help in collecting relevant data and the colleagues Dr. Matthew Copeland, Dr. Marja-Leena Heikkila-Horn, and Dr. Hardina Ohlendorf, for their useful comments. Additionally the authors are thankful to the anonymous reviewers for their insights that greatly assisted in improving this paper.

2 Popularly known as the Wat Khaek. Founded by the diasporic Southern Indian community during the reign of King Rama IV (1851-1868).

3 Thai country music from the Northeast of Thailand developed in the first half of the twentieth century but the word luk thung came into use only in the 1960s. The luk thung songs typically reflect the hardship of everyday life among the rural poor class.

4 One of the newly developed areas on the Thonburi side of Bangkok with several department stores and restaurants and provides access to important tourist sites within both Bangkok and suburban areas.

5 One of the three major gods in the Hindu pantheon including Brahma and Vishnu.

6 Heramba Ganesa is the 11th among the 32 different forms of Ganesh, also seen as the protector of the weak. In this form, Ganesa appears with five heads and ten hands and the worship of this form is believed to bring confidence to the weak, overcome fears and knowledge to accomplish tasks.

7 Generally depicted seated or standing with four arms, an elephant head, potbellied and one tusk. He normally holds either of the four in his hands: svadanta (his own tusk); kapittha (wood-apple); modaka (sweet also known as laddu); ankusha (elephant goad); pasha (noose); naga (snake); parashu (axe); rosary; lotus; or mulaka (radish). His vehicle is a musika (mouse) and he ties a snake around his waist (Dalal 2010: 142).

8 A festival celebrated during the month of Bhaadrapada according to the Hindu lunar calendar and usually falls in August or September.

$9 \quad$ Ganesa Chaturthi is believed to be ancient but was not a part of Maharasthra's tradition until introduced by the Maratha Empire. In 1893, Tilak re-invented the Ganesa Chaturthi 
(birthday celebration of Ganesa) from annual family celebration into a public event. This was a way of building national spirit and show unity of the Hindu society by turning the festival into a community-based enterprise (Nejad 2015: 273-274; Metcalf and Metcalf 2012: 151-152).

10 Tilak (1856-1920) was an Indian nationalist and the first popular leader of the Indian Independence movement against the British colonial rule.

11 The caste system in India is a social stratification of people into four main groups, priests, warriors, merchants and the peasants. While the first three are considered as the upper castes, the peasants fall under the category of lower caste. The individual membership comes through birth and there is a mutual interdependence within given occupation with defined ritual duties, roles, attributes surrounding purity and pollution, specific customs and traditions of worship. See O’Malley 1935: 65-92.

See Purkayastha 2016.

3 See Sukumar 2003.

14 See Kitiarsa 2005.

15 Stengs defines Thainess as being able to "integrate modernisation in a Thai manner" in addition to being a symbol of "pride for not being colonised." See Stengs (2012). The miracle happened on 21 September 1995 and lasted only for 24 hours.

Interview on 22 January 2016. The Hindu Brahmin, prefers to be called by his last name Tripathi, is originally from Gorakhpur (a city in the northeastern part of Indian state of Uttar Pradesh) and works independently without being associated with any particular Hindu temple in Thailand. He has been providing religious services to both diasporic Hindu community and the Thai community since 1991. Interviewed on 20 February 2016.

19 See McDaniel 2011: 23-71 and McDaniel 2014.

20 The term icon generally includes several devotional objects, such as statues, amulets, wall paintings, mosaics, buildings, monasteries, written texts or even a person. Here the term refers to an object of veneration like statues and amulets.

21 An icon seller running a shop opposite a department store in Rangsit, interviewed on 21 February 2016.

22 The Goddess of compassion and mercy in Mahayana Buddhism, as a bodhisattva venerated among the East Asian Buddhist.

23 The monkey king, one of the most famous Chinese legends, a character from the classic novel entitled The Journey to the West.

24 Interviewed on 27 January 2016.

25 The sculptor has majored in arts and sculptures and holds two master's degree.

26 Known as the Lakshmi Ganapati, this is one of the forms listed among the thirty-two names of Ganesa in the Mudgala Purana. Lakshmi Ganapati refers to Ganapati the fortunate and in this form, he is with his wives Siddhi (Achievement) and Buddhi (Wisdom). He has eight hands and both of his consorts hold while lotus flowers.

27 Known to the locals as the Pikanet shrine in the Huay Kwang district, the shrine is one of the most famous Ganesa shrines in Bangkok.

$28 B$ Budhi, often replaced with Riddhi, signifies prosperity.

29 The exchange rate as of 20 October 2016 is approximately USD $\$ 1 / 35$ baht

30 Interviewed on 2 March 2016. 


\section{REFERENCES}

Aden, R. 2013. The right to sacred things: Symbol, myth, and ritual. In Religion today: $A$ critical thinking approach to religious studies, ed. Lanham, M., 125-182. London: Rowman \& Littlefield.

Bainbridge, S. W. and Stark, R. 1985. The future of religion: Secularization, revival, and cult formation. Berkeley and Los Angeles: University of California Press.

2003. Cult formation: Three compatible models. In Cults and new religious movements: A reader, ed. Dawson, L. L., 59-70. Oxford: Blackwell Publishing.

Brown, R. L. 1991. Ganesa in Southeast Asian art: Indian connections and indigenous developments. In Ganesh: Studies of an Asian god, ed. Brown, R. L., 171-233. Albany: State University of New York.

Coedes, G. 1968. The Indianized states of Southeast Asia. Honolulu: East-West Center Press.

Comaroff, J. and Comaroff, J. L. 2000. Millennial capitalism: First thoughts on a second coming. Public Culture 12 (2): 291-343, https://doi.org/10.1215/08992363-12-2291.

Dalal, R. 2010. Hinduism an alphabetical guide. New York: Penguin.

Dhavalikar, M. K. 1991. Ganesa: Myth and reality. In Ganesh: Studies of an Asian god, ed. Brown, R. L., 49-68, Albany: State University of New York.

Ghurye, G. S. 1962. Gods and men. Mumbai: Popular Book Depot.

Hendry, J. 1999. An introduction to social anthropology. London: Macmillan Press, https://doi.org/10.1007/978-1-349-27281-5.

Huntington, E. and Shaw, E. B. 1951. Principles of human geography. New York: John Wiley and Sons.

Jackson, P. A. 1999. Royal spirits, Chinese gods, and magic monks: Thailand's boomtime religions of prosperity. South East Asia Research 7 (3): 245-320, https://doi. org/10.1177/0967828X9900700302.

Kitiarsa, P. 2005. Beyond syncretism: Hybridization of popular religion in contemporary Thailand. Journal of Southeast Asian Studies 36 (3): 461-487, https://doi. org/10.1017/S0022463405000251.

2008. "Buddha Phanit." In Religious commodifications in Asia, ed. Kitisara, P., 120-143. London and New York: Routledge.

. 2010. Toward a sociology of religious commodification. The new Blackwell companion to the sociology of religion, ed. Turner, B. S., 563-579. West Sussex: Blackwell, https://doi.org/10.1002/9781444320787.ch25. 2012. Mediums, monks, and amulets: Thai popular Buddhism today. Chiang Mai: Silkworm Books.

Kopytoff, I. 1986. The cultural biography of things: Commoditazion as process. In The social life of things: Commodities in cultural perspective, ed. Appadurai, A., 64-92. Cambridge: Cambridge University Press.

Lochtefeld, J. G. 2002. The illustrated encyclopedia of Hinduism. New York: Rosen.

Mabbett, I. W. 1977. The "Indianization" of Southeast Asia: Reflections on the prehistoric sources. Journal of Southeast Asian Studies 8 (1): 1-14, https://doi.org/10.1017/ S0022463400015617. 
McDaniel. J. 2011. The lovelorn ghost and the magical monk: Practicing Buddhism in modern Thailand. New York: Columbia University Press, https://doi.org/10.7312/ mcda15376.

2014. The material turn: An introduction to Thai sources for the study of Buddhist amulets. In Material culture and Asian religions: Texts, image, object, eds. Fleming, B. J. and Mann, R. D. 135-150. New York: Routledge.

Mcgirk, T. 1995. Hindu world divided by a 24-hour wonder. Independent, 25 September. http://www.independent.co.uk/news/uk/hindu-world-divided-by-a-24-hourwonder-1602382.html (accessed 30 September 2017).

Metcalf, D. B. and Metcalf, R. T. 2012. A concise history of Modern India, 3rd ed. New York: Cambridge University Press, https://doi.org/10.1017/CBO9781139207805.

Miller, D. 1987. Material culture and mass consumption. Oxford: Blackwell.

Nejad, M. R. 2015. Religious processions as a means of social conciliation. In Communitybased urban violence prevention, eds. Mathey, K. and Matuk, S., 268-279. New York: Transcript Verlag.

O'Malley, L. S. S. 1935. Popular Hinduism: The religion of the masses. New York: Cambridge University Press.

Park, C. 2004. Religion and geography. In Routledge companion to the study of religion, ed. Hinnells, J. R., 439-455. London: Routledge.

Purkayastha, B. 2016. Bringing goddess down to earth. In Emergent possibilities for global sustainability: Intersections of race, class and gender, eds. Godfrey, P. and Torres, D., 93-103. Abingdon, Oxon: Routledge.

Scott, R. 2017. Contemporary Thai Buddhism. In The Oxford handbook of contemporary Buddhism, ed. Jerryson, M. K. New York: Oxford University Press.

Segaller, D. 2005. Thai ways. Chiang Mai: Silkworm Books.

Smart, N. 1989. The world religions. New York: Cambridge University Press.

Smith, J. Z. 1978. Map is not territory: Studies in the history of religions. Chicago: University of Chicago Press.

Stengs, I. 2012. Portraits that matter: King Chulalongkorn objects and the sacred world of Thai-ness. In Things: Religion and the question of materiality, eds. Houtman, D. and Meyer, B., 137-150. New York: Fordham University Press, https://doi. org/10.5422/fordham/9780823239450.003.0009.

Suarez, T. 1999. Early mapping of Southeast Asia. Singapore: Periplus Editions.

Sukumar, R. 2003. The living elephants: Evolutionary ecology, behaviour, and conservation. New York: Oxford University Press.

Tambiah, S. J. 1984. The Buddhist saints of the forest and the cult of amulets: A study in charisma, hagiography, sectarianism, and millennial Buddhism. Cambridge: Cambridge University Press.

Wilson, A. 2008. The sacred geography of Bangkok's markets. International Journal of Urban and Regional Research 32 (3): 631-642, https://doi.org/10.1111/j.14682427.2008.00801.x. 